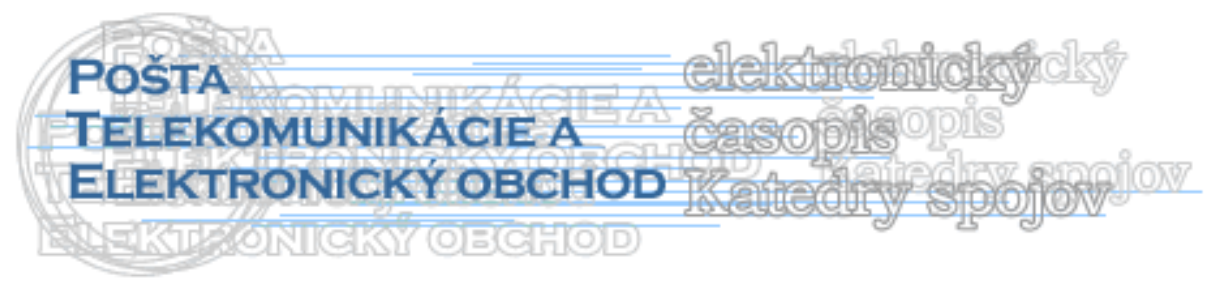

\title{
THE FORMATION AND DEVELOPMENT OF SOCIAL CAPITAL OF THE POSTAL SERVICE
}

\author{
Olga Liva ${ }^{1}$ Ivan Stríček ${ }^{2}$
}

\begin{abstract}
The article deals about development of social capital in postal services, which currently present one of most needed area of improvement in this sector. Mainly for national postal operators is necessary to improve approach of employees in affiliates.
\end{abstract}

Keywords: improvement, postal services, social, capital

The turbulence of the modern world requires a revision of views on the formation of management models of the enterprise. Financial and organizational instruments cease to be in the focus of business activities. Instead, intangible assets are becoming a core of management development. At this stage of economic evolution, a characteristic of the level of relationships in the company determines its further development. Trust, social networks, social value and business reputation are ones of the key dominants in the post-industrial economy. The Postal service is the industry which requires a high level of social capital. Indeed, the social cohesion of employees, the development of communication channels and high level of trust are the pledge of the competitive advantages of any organization, especially the postal services.

Currently, there are many scientific achievements concerning social capital. However, the typical mechanism or concept has not been produced in enterprise economy, including in the field of postal services. Therefore, the aim of this article is to examine the basic tenets of the development and management of social capital on the example of organizations that provide postal services.

The term "social capital" was used first in 1916 by L. J. Hanifan [2], which attracted attention to the importance of collective interaction in school. But the founder of the concept of social capital as an economic category is considered Bourdieu which also highlights social capital beside the levels of economic and cultural capital. Most global understanding of social capital provides by Francis Fukuyama [3], which highlights the interdependence between the prosperity of society and the level of social capital. Further scientific interpretation of social capital has found place in the writings of such scholars as Adler and Kwon [1], Putnam [6], Portes [5], Woolcock [7] and etc.

However, now is remained a number of unresolved issues related to the formation and development of social capital as an economic asset of the organization. First of all, it is necessary to distinguish social capital into a distinct category of management. It should be not equated social capital with human resources, social responsibility and customer capital. If human capital as form of the skills and expertise of individual workers, social capital occurs

\footnotetext{
${ }^{1}$ Olga Liva, Kyiv National Economic University named after Vadym Hetman, 1st year PhD.' Student in Enterprise Strategy Department, e-mail:olivam@ukr.net

${ }^{2}$ Ivan Stríček, Žilinská univerzita v Žiline, Fakulta prevádzky a ekonomiky dopravy a spojov, Katedra spojov, Univerzitná 8215/1, 01026 Žilina, Slovenská republika, tel.: +421 41513 3144, e-mail: stricek@fpedas.uniza.sk
} 
only in relations between people. Social responsibility can be part of a policy to the strengthening social capital, but it is not the source of the development of social capital. Clients capital can be formed only in the presence of a considerable stock of social capital in the company. Some scholars refer social capital to intellectual capital. Nevertheless, in our view, social capital is only an aggregate of intellectual capital.

Let's look in details at the nature of social capital. After analyzing the leading concepts about this concept, we have concluded that social capital is an intangible factor of production, which is formed in the relationship within the company and in interaction with all stakeholders, it helps to increase profit by reducing transaction costs and increasing the efficiency of the organization. Among the main elements of social capital should allocate trust, social networks, business reputation, social and values norms. By itself social capital is difficult to consider as an economic factor of income. Because its amorphous nature does not allow to distinguish a direct link between the results of the company and the level of social capital.. But it is quite easy to notice that low efficiency accompanied by the absence of social capital. For example, if low level of trust and reputation for a postal service is available for company, the client is unlikely to want to use the services of this organization, experiencing for the safety of his property. Or undeveloped social networks leads to an increase in transaction costs. A lack of social values and norms of workers is unlikely to promote the innovation or organizational development of postal services.

Low quality and deformation of social capital can be expressed in the following processes at the enterprise of postal service:

- High staff turnover;

- Poor psychological climate in the collective;

- Lack of established values and norms;

- Reduction customer trust to the company that causes falling sales of services.

Therefore, social capital is a specific management filter that transforms the human, organizational and financial resources, forming client and financial assets of the organization (Fig.1).

How is the social capital formed in the postal services?! Sprouts of social capital penetrate into the business structure since the inception of the organization. There is dominant opinion that financial and material capital is the most important in nucleation postal enterprises, but the lack of social capital can quite easy to refute this statement. After all, at the stage of creating the most significant impact have social relationships and presence social networks of the founders that help to unify the postal enterprise in the market, attract funds and find the first customers. At the stage of development of postal services the most weight are played such following elements of social capital as trust and social networks. At the stage of maturity is more important to insert specific social norms and values, to enhance the level of business reputation. Moreover, the development of social values for the postal service, in our opinion, would be advisable to take into account the idea of shared value of Michael Porter [6]. According to this concept postal company must promote such values that would be common for customers and clients. Postal service must implement the global needs of society in their social norms. These needs can meet the objectives of energy savings, budget resource of consumers or ecological packaging which would not pollute the environment. 


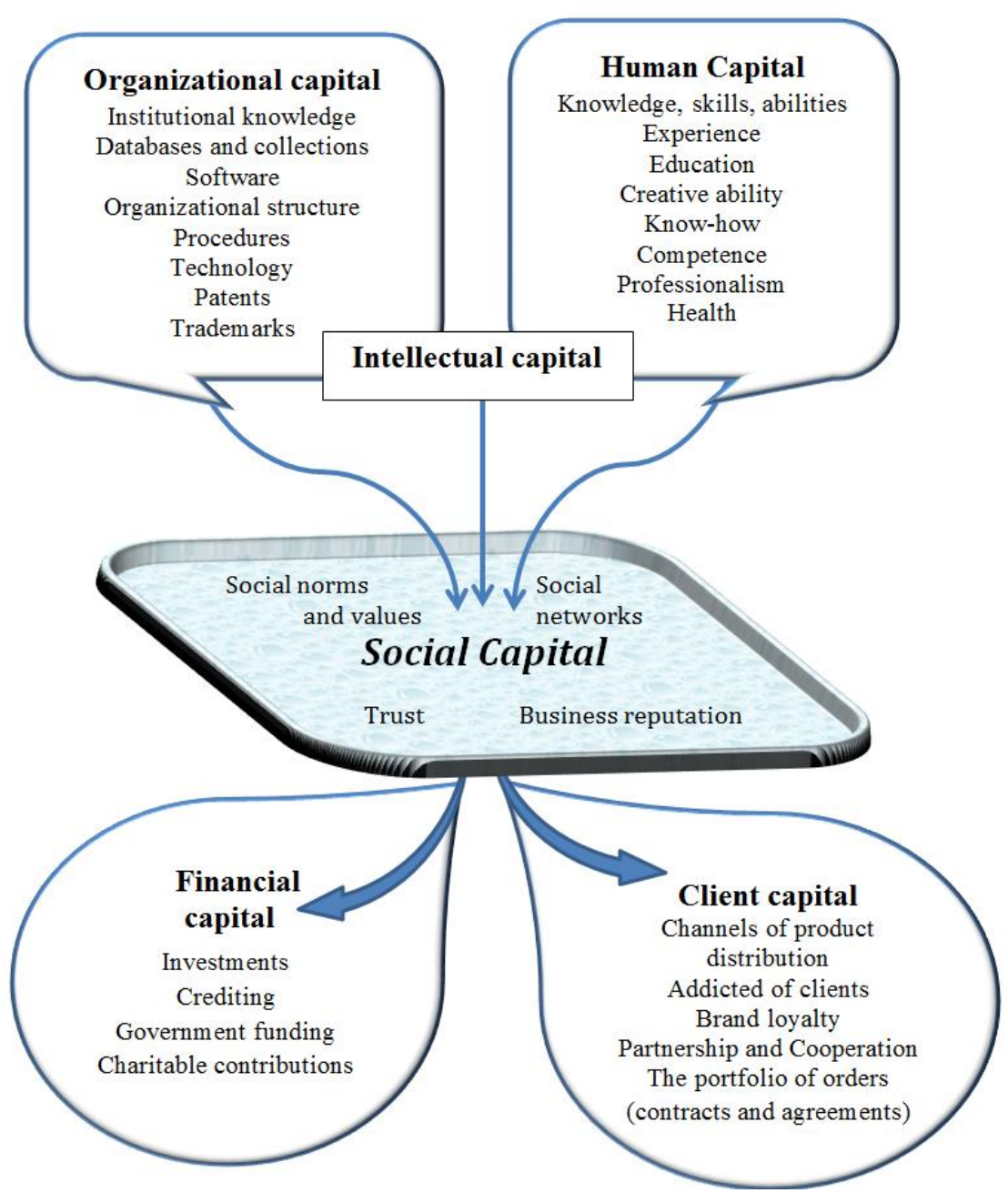

Fig.1. Place of social capital in the economic structure of the organization

Social values of the organization may arise from the policy of social responsibility in the company. For example, social values in postal organizations can be formed due to the availability of such social superstructures as kindergartens, recreation programs and free education for employees. All these measures are useful not only for employees but also for own sake of company, because it is a contribute to the creative spirit and to increasing productivity, which has a direct impact on profits. Another issue that needs attention in the postal service is setting up the optimal delivery routes in parallel with the reduction of carbon emissions by cars which transport parcels. Switching to ECO fuel use will contribute not only cost savings but also will help to save the environment. Thus, the postal service creates the joint social values. So primarily, for the managing apparatus should be established social norms in the company that would entail the benefits to all stakeholders of the postal service.

Trust is very important at the stage of development of service enterprises. Trust is the determining factor of success of any telecommunications organization. After all, trust acts as support for a strong and stable customer capital. Trust in postal organization is the evidence of confidence in quality service. The second side of trust in the organization is the relationship in a collective. If there is trust, then will take place process of generating ideas, delivering creative initiatives to the management of organization. If there is no trust, then will be spread conflicts, will be formed an unfavorable psychological climate that will lead to an additional financial burden. 


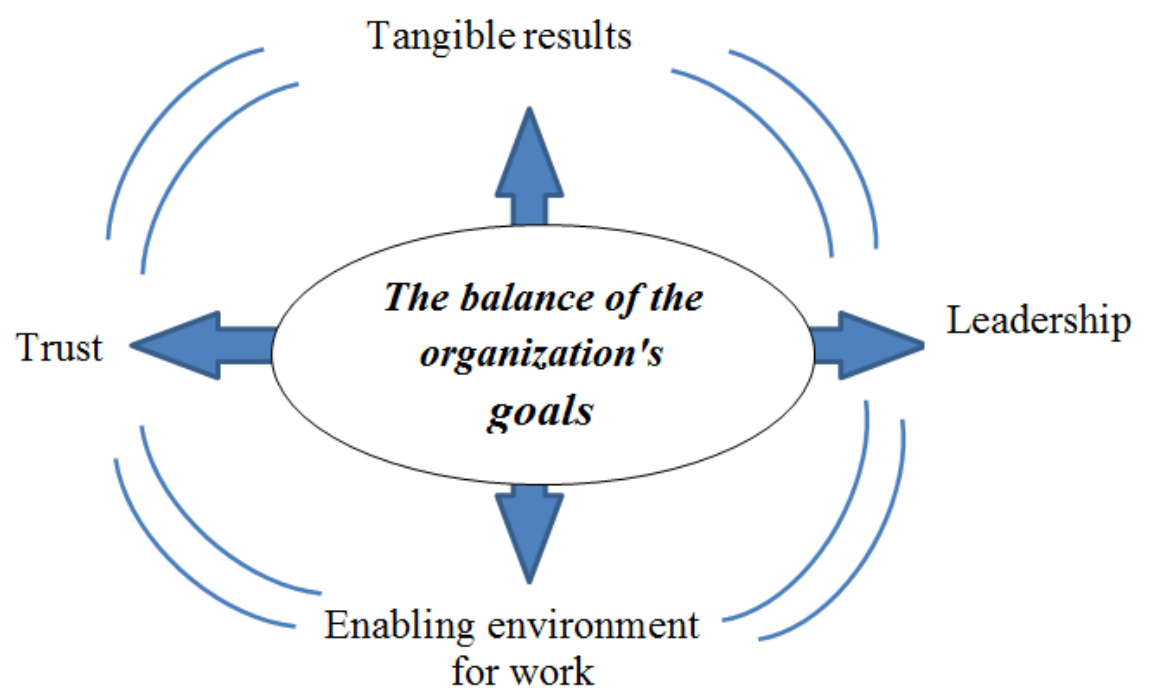

Fig. 2. The balance of the organization's goals as the management instrument of social capital

Social networks are channels for the disseminating information and knowledge. They are essential in creation of marketing channels, selection of personnel or implementation of innovations as soon as possible. In our view, it is appropriate to allocate internal and external social networks. Internal social networks are relationships between employees that may be formed on basis of information networks and by establishing verbal contact. A key place in external social networks occupy online networks such as Facebook and Linked in, where potential customers and employees can find information on postal services.

At the stage of maturity of postal service is very important to ensure the appropriate level of business reputation, which is based on respect, shared values and loyalty. Business reputation is a manifestation of social capital in market relations.

Useful tools in the management of social capital will be drawing up the balance of the organization's goals (Fig. 2).

General interdependence between social capital and efficiency of the company can represented in the form of cubic parabola. Improving social capital in a one conditional units value leads to an increase in efficiency by 3 conditional units value (Fig. 3).

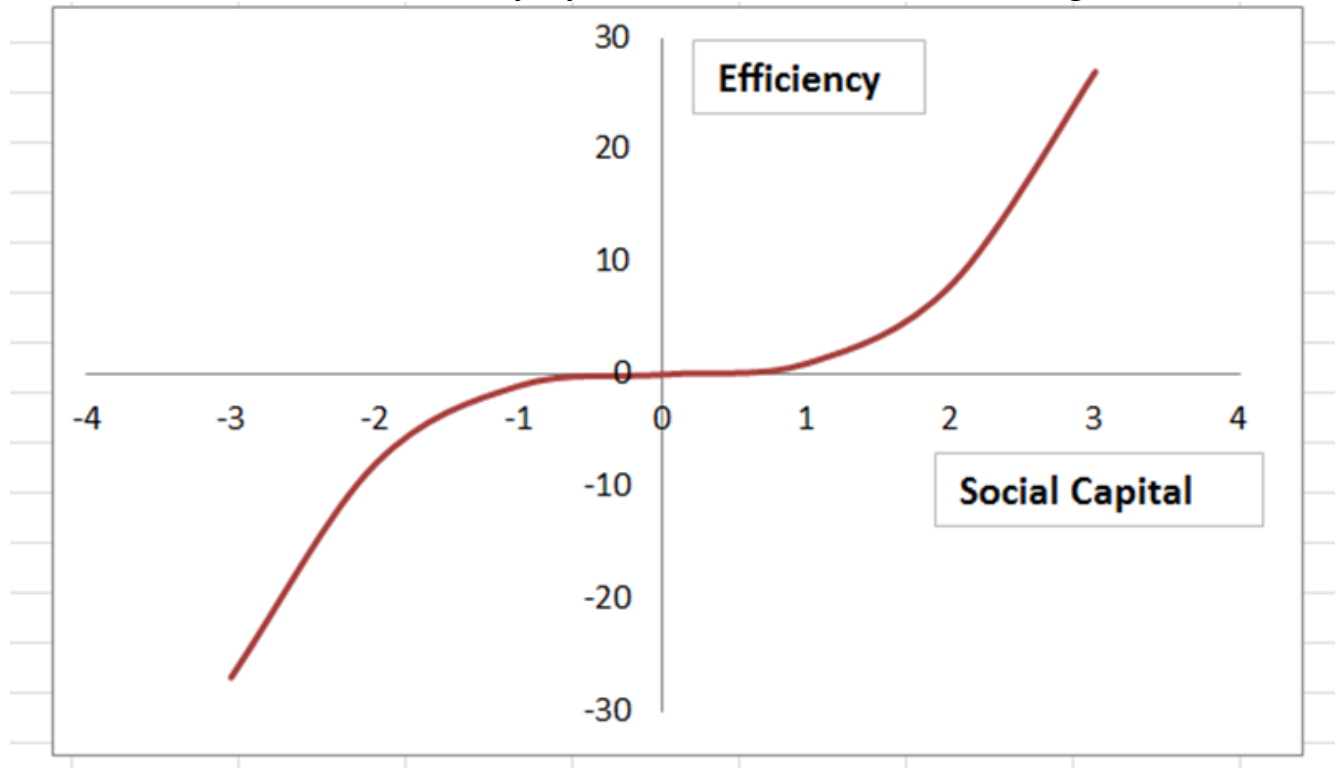

Fig. 3. Interrelation between of efficiency and social capital 
The practical essence of the formation of social capital is displayed on example of "Nova Poshta" which is the modern Ukrainian postal service. "Nova Poshta" is a company that less than a decade has become the leader of Ukrainian postal services market. It owes much to the high level of social capital for this rapid development. Trust at "Nova Poshta" is guaranteed by reliability and timeliness of delivery. The company is actively developing its intellectual capital. Friendly relations and ease in communication between employees have facilitated the introduction of modern management techniques. Mothballed bureaucracy is missing for "Nova Poshta".

Quite a lot of workers last 30 years are in the managerial staff, which active interaction creates new ways of strategic development of the company. Social cohesion of collective paves the way for national cultural traditions. Recently workers "Nova Poshta" outlined the Ukrainian living emblem from persons. And accordingly this strengthens business reputation in the eyes of Ukrainian who prefers national patriotic producers. It should be noted that social capital was not subject of management in the "Nova Poshta", but it is become automatically integrated phenomenon in the process of historical circumstances. However, this example clearly demonstrates the relationship between the prosperity of the company and the level of social capital.

The process of management of social capital needs further research, which should include so objectives:

- Diagnostics of social capital using the questionnaire method and expert assessments (analysis of existing social norms and values in the business, determine the level of trust on the part of employees and customers, monitoring of social networks, rating business reputation of the firm);

- Formation of the proposals about strengthen social capital in the organization. For example, you can improve trust by establishing of a transparent relationships, by the fulfillment of obligations, by demonstration of respect and by the ability at first to hear the opinion of the employee, by the dismantling of past conflicts, by the prevalence of loyalty, by the clarify expectations about achieve results, by the awareness of the real situation of the company;

- Selection and implementation of the most influential and priority measures to enhancing of social capital;

- Development management techniques of social capital.

One of the most effective methods in the formation of social capital is the personal relationships coaching which investigates various points of view of employees, managers and customers to each other, determines brake elements of relationships and developes vision for effective interaction.

\section{Conclusion}

Social capital is the original multiplier of available resources, that can have a negative or positive effect on postal service depending on its level. The key elements of social capital management are the social norms and values, business reputation, social networks and trust. Streamline management of social capital will reduce the transaction costs, increase the productivity of workers and expand sales channels of postal service.

\section{References}

[1] ADLER, Paul S.; KWON, Seok-Woo. Social capital: Prospects for a new concept. Academy of management review, 2002, 27.1: 17-40.

[2] HANIFAN, Lyda J. The rural school community center. Annals of the American Academy of political and Social Science, 1916, 67: 130-138. 
[3] FUKUYAMA, Francis. Trust: The social virtues and the creation of prosperity. New York: Free Press, 1995.

[4] PORTER, Michael E.; KRAMER, Mark R. Creating shared value. Harvard business review, 2011, 89.1/2: 62-77.

[5] PORTES, Alejandro. Social capital: Its origins and applications in modern sociology. LESSER, Eric L. Knowledge and Social Capital. Boston: Butterworth-Heinemann, 2000, 43-67.

[6] PUTNAM, Robert D. Bowling alone: America's declining social capital. Jouenal of Democeacy, 1995, 6: 68.

[7] WOOLCOCK, Michael. The place of social capital in understanding social and economic outcomes. Canadian Journal of Policy Research, 2001, 2.1: 11-17.

\section{Grant support}

This contribution was undertaken, as parts of the research project VEGA 1/1321/12 Research of new trends in management in the era of globalization, VEGA 1/0895/13 Research on strategic business management as promoting competitiveness in a dynamic business environment. 